\title{
The Curriculum Ideology Recommended by Novice Teachers for Life Sciences in South Africa
}

\author{
Lindelani Mnguni ${ }^{1 *}$ \\ ${ }^{1}$ Department of Science and Technology Education, University of South Africa, SOUTH AFRICA
}

Received 14 March $2018 \cdot$ Revised 22 March 2018 - Accepted 26 March 2018

\begin{abstract}
South African has adopted the Curriculum and Assessment Policy Statement curriculum, which is aimed at promoting citizenship education. However, the extent to which teachers subscribe to the same ideology has yet to be investigated. The current study explored the curriculum ideology recommended by teachers in Life Sciences, in order to determine the extent to which they support citizenship education. Participants were postgraduate teachers employed in various government schools in Gauteng, South Africa. A semi-structured questionnaire was used for data collection. Results show that teachers recommended multiple ideologies with greater support for the student-centred and service-centred ideologies. The citizenship-centred ideology was least recommended. These findings suggest that citizenship education may not be realized, as teachers do not recommend the relevant ideology.
\end{abstract}

Keywords: curriculum ideologies, curriculum reforms, Life Sciences, teachers

\section{INTRODUCTION}

Gagne (1967, p. 23) defines a curriculum as a "sequence of content units arranged in such a way that the learning of each unit may be accomplished as a single act, provided the capabilities described by specified prior units (in the sequence) have already been mastered by the student". Similarly, Popham and Baker (1970) define a curriculum as the planned learning outcomes for which the school is responsible. Taylor (1957, p. 79) however defines a curriculum as "all the learning experiences planned and directed by the school to attain its educational goals". In the current study, these and other definitions of a curriculum are combined and a curriculum is defined as the documented outline of predetermined learning outcomes, subject matter and sequence of learning experiences developed by educational authorities (Mnguni, 2013).

Educational authorities around the world regularly engage in curriculum review processes in order to respond to global and local emerging research, socio-economic and political dynamics. These include translation of the new ideas into new educational practices (Pietarinen, Pyhältö \& Soini, 2017), standardizing content and learning outcomes (Porter, Fusarelli \& Fusarelli, 2015), renewing educational content and experiences (Huang, 2004) as well as introducing student-centred curricula, content and pedagogies (Bulut, 2007). In South Africa, the government has imposed the Curriculum and Assessment Policy Statement (CAPS), which specifies the purposes of learning, the content to be taught as well as the assessment procedures to be followed (Spaull, 2013). As part of this, the CAPS curriculum has introduce citizenship education values to ensure that students, and the society, become selfless, clear-thinking and enlightened citizens who participate in the reconstruction and empowerment of the society (Waghid, 2002).

Since 1994, South Africa has had three curriculum revisions, which led to the adoption of the National Curriculum Statement (NCS) in 2002 and the current CAPS curricula which has been followed since 2012 (Chisholm, 2003; du Plessis, 2013; Jansen, 1998; Msila, 2007). The underlying socio-political premise for these reforms was the promotion of citizenship education as can be understood from Nelson Mandela's view that education is the tool that can be used to change the world (Mandela, 2003). In this regard, curriculum reforms in South Africa are generally aimed at "redressing the inequalities and injustices caused by the apartheid regime policies, using education as its tool" (Bantwini, 2010, p. 84). As such, the objective of these curriculum reforms range

(C) 2018 by the authors; licensee Modestum Ltd., UK. This article is an open access article distributed under the terms and conditions of the Creative Commons Attribution License (http://creativecommons.org/licenses/by/4.0/). $\square$ mngunle@unisa.ac.za (*Correspondence) 


\section{Contribution of this paper to the literature}

- The current research explored the curriculum ideology recommended by novice teachers for Life Sciences.

- Teachers recommended the student-centred and service-centred ideologies.

- The citizenship-centred ideology which supports citizenship education was least recommended. As a result, citizenship education envisage in the Life Sciences curriculum may not be realized.

from cleansing syllabi of racist language and controversial and outdated content, to the introduction of content and pedagogy which promotes social justice as defined in the Constitution of the Republic of South Africa (du Plessis, 2013; Van Deventer, 2009). However, regardless of these curriculum reforms, poor student performance and a number of socio-scientific challenges remain well founded as evidenced in the recent so-called \#FeesMustFall university student protests (Luescher, Loader \& Mugume, 2017). In these protests, students and academics called amongst other things for the decolonization and Africanization of the curriculum by teaching context-specific content knowledge (Le Grange, 2016). This is because researchers, students and members of the society in general have identified a lack of curriculum relevance as related to the poor implementation of curriculum reforms (Stuckey, Hofstein, Mamlok-Naaman \& Eilks, 2013). What is not well documented however are the ideological impediments that hinder the effective implementation of the curriculum reforms.

\section{Role of Teachers in Curriculum Reform}

Alsubaie (2016) argues that teachers are the most important people in the implementation of curriculum reforms. Teachers are viewed as significant agents of curriculum change and their preparedness to adopt curriculum reforms is crucial in shaping the success or failure of curriculum change (Lee, Yin, Zhang \& Jin, 2011). As such, it is imperative that teachers be intrinsically involved in curriculum development. If not, then teachers are burdened with the need to learn the curriculum and adjust their preferred curriculum ideologies, teaching philosophies and methods to suit the needs of the new curriculum. In these instances, teachers may be confronted with circumstances that limit their effectiveness, which may lead to regular and harsh public criticism due to poor student performance (Eacute \& Esteve, 2000).

Another key factor in the success of implementing curriculum reform is teacher preparedness to adopt new curriculum ideologies, new content and new ways of teaching as may be required in the reformed curriculum (Lee \& Yin, 2005). Sadly, however, there is evidence that teachers are not always empowered to implement curriculum reforms (Alsubaie, 2016). Pre-service and in-service teacher-training programmes tend to focus only on pedagogical content knowledge rather than curriculum theory including ideologies that inform curricula (Mnguni, 2013; Sweetland \& Hoy 2000). Kelchtermans (2005) also argues that underlying teaching philosophies, teachers' emotions and normative beliefs, which are grounded on structural condition of the teaching job, are often ignored in curriculum reformation. This is in line with Ajzen (1991), who argues that behaviour such as teaching is associated with normative beliefs. Consequently, if curriculum reforms impose different normative beliefs they may trigger intense resistance (Bantwini \& King-McKenzie, 2011). It is for this reason that the current researcher explores teachers' recommended curriculum ideology in order to determine possible areas of conflict between teachers and the curriculum. A curriculum ideology refers to,

\footnotetext{
"the overarching aims or purposes of education, the nature of the child or student, the way learning must take place, the role of the teacher during instruction, the most important kind of knowledge that the curriculum is concerned with and the nature of this kind of knowledge, and the nature of assessment" (Schiro, 2008: 7).
}

Of significance in the current research is not teacher preparedness to implement a curriculum as this has been exhaustively explored (e.g. Ramatlapana \& Makonye, 2012). Instead, the researcher was more interested in determining whether teachers' recommended curriculum ideologies would support citizenship education. This is because Goodlad and associates (1979) suggest that there are at least five different levels of a curriculum, namely, the ideological, formal, perceived, operational and the experienced levels of the curriculum. As such, curriculum reforms at any one level are not guaranteed to be transferred to another. In fact Kurz, Elliott, Wehby and Smithson (2010) show that there are instances where the intended, planned and enacted curricula are not aligned leading to poor implementation of curriculum reforms. Other researchers (e.g. Bantwini, 2010; Mnguni, 2017) have also shown that differing ideologies may trigger misinterpretations and alternative interpretations during the translation of the curriculum through the different levels. One wonders therefore whether teachers share the same curriculum ideologies with the curriculum. 
Table 1. A comparison of curriculum ideologies (adapted from Schiro, 2008)

\begin{tabular}{|c|c|c|c|c|c|}
\hline \multicolumn{2}{|c|}{ Curriculum features } & \multirow{2}{*}{$\begin{array}{c}\begin{array}{c}\text { Discipline-centred } \\
\text { ideology }\end{array} \\
\text { Understanding }\end{array}$} & \multirow{2}{*}{$\begin{array}{c}\begin{array}{c}\text { Service-centred } \\
\text { ideology }\end{array} \\
\text { Doing / action }\end{array}$} & \multirow{2}{*}{$\begin{array}{c}\begin{array}{c}\text { Student-centred } \\
\text { ideology }\end{array} \\
\text { Actualizing oneself }\end{array}$} & \multirow{2}{*}{$\begin{array}{c}\begin{array}{c}\text { Citizenship-centred } \\
\text { ideology }\end{array} \\
\text { Interpret and } \\
\text { reconstruct society }\end{array}$} \\
\hline Aim of the subject & Purpose for knowledge & & & & \\
\hline \multirow[t]{2}{*}{ Content knowledge } & Nature of knowledge & Didactic statements & Capabilities for action & Personal meanings & $\begin{array}{l}\text { Intelligence and a } \\
\text { moral stance }\end{array}$ \\
\hline & Source of knowledge & $\begin{array}{l}\text { Objective reality as } \\
\text { interpreted by } \\
\text { academic disciplines }\end{array}$ & $\begin{array}{l}\text { Normative objective } \\
\text { reality as socially } \\
\text { interpreted }\end{array}$ & $\begin{array}{l}\text { Individuals' personal } \\
\text { creative response to } \\
\text { experience }\end{array}$ & $\begin{array}{c}\text { Individuals' } \\
\text { interpretation of } \\
\text { society's past, present } \\
\text { and future } \\
\end{array}$ \\
\hline \multirow[t]{5}{*}{ Instructional Process } & Learning viewed from & Transmitter & Transmitter & Receiver & Transmitter \\
\hline & Primary function of learning & Social transmission & Social transmission & Growth & Social transmission \\
\hline & Result of learning & Changed mindset & Changed behaviour & Changed mindset & Changed behaviour \\
\hline & $\begin{array}{c}\text { Primary actor during } \\
\text { learning }\end{array}$ & Agent & Agent/student & Student & Agent/student \\
\hline & Student readiness & $\begin{array}{l}\text { Simplification of } \\
\text { difficult topics }\end{array}$ & $\begin{array}{l}\text { Providing prerequisite } \\
\text { behavioural } \\
\text { capabilities }\end{array}$ & Stages of growth & $\begin{array}{l}\text { Gestalt of prior } \\
\text { experience }\end{array}$ \\
\hline \multirow[t]{4}{*}{ The student } & Role during learning & Passive & Active & Active & Active \\
\hline & Teachers focuses on & Student's mind & Student's behaviour & Student's mind & Student's behaviour \\
\hline & $\begin{array}{c}\text { Teachers concerned with } \\
\text { children }\end{array}$ & As they ought to be & As they ought to be & As they are & As they ought to be \\
\hline & Viewing children & $\begin{array}{c}\text { In relation to } \\
\text { standardized norms }\end{array}$ & $\begin{array}{c}\text { In relation to } \\
\text { standardized norms }\end{array}$ & As individuals & $\begin{array}{c}\text { In relation to } \\
\text { standardized norms }\end{array}$ \\
\hline \multirow[t]{6}{*}{ Teaching } & Role of teacher & Transmitter & Supervisor & Facilitator & Colleague \\
\hline & $\begin{array}{l}\text { Standards used to measure } \\
\text { teacher effectiveness }\end{array}$ & $\begin{array}{l}\text { Accurate presentation } \\
\text { of discipline }\end{array}$ & $\begin{array}{l}\text { Efficiency of student } \\
\text { learning }\end{array}$ & $\begin{array}{l}\text { Facilitation of } \\
\text { growth }\end{array}$ & $\begin{array}{l}\text { Effective transference } \\
\text { of the vision }\end{array}$ \\
\hline & Teachers stimulate & Uniformity & Uniformity & Diversity & Uniformity \\
\hline & Teachers & $\begin{array}{l}\text { Directly implement } \\
\text { curriculum }\end{array}$ & $\begin{array}{l}\text { Directly implement } \\
\text { curriculum }\end{array}$ & $\begin{array}{l}\text { Adapt curriculum } \\
\text { (according to } \\
\text { children's needs) }\end{array}$ & $\begin{array}{l}\text { Adapt curriculum } \\
\text { (according to social } \\
\text { concerns) }\end{array}$ \\
\hline & Media used during learning & Didactic discourse & $\begin{array}{c}\text { Programmed } \\
\text { instruction }\end{array}$ & $\begin{array}{c}\text { Child-environment } \\
\text { interaction }\end{array}$ & Group dynamics \\
\hline & Intent of teaching & $\begin{array}{l}\text { To advance students in } \\
\text { a discipline }\end{array}$ & $\begin{array}{l}\text { To prepare students to } \\
\text { perform skills }\end{array}$ & $\begin{array}{l}\text { To stimulate child } \\
\text { growth }\end{array}$ & $\begin{array}{l}\text { To acculturate } \\
\text { students into } \\
\text { educators' vision }\end{array}$ \\
\hline \multirow[t]{4}{*}{ Assessment } & $\begin{array}{l}\text { Purpose of evaluation to the } \\
\text { evaluator }\end{array}$ & $\begin{array}{l}\text { Rank students for a } \\
\text { future in the discipline }\end{array}$ & $\begin{array}{l}\text { Certify that students } \\
\text { have the skills }\end{array}$ & $\begin{array}{c}\text { Diagnose students' } \\
\text { abilities to facilitate } \\
\text { growth } \\
\end{array}$ & $\begin{array}{c}\text { Measure student } \\
\text { progress with respect } \\
\text { to ability }\end{array}$ \\
\hline & Nature of assessment tools & Norm reinforced & Criterion reinforced & $\begin{array}{c}\text { Informal subjective } \\
\text { diagnosis }\end{array}$ & $\begin{array}{c}\text { Informal subjective } \\
\text { diagnosis }\end{array}$ \\
\hline & Assessments are & Objective & Objective & Subjective & Subjective \\
\hline & Point of assessment & After instruction & After instruction & During instruction & During instruction \\
\hline
\end{tabular}

\section{Theoretical Framework of the Research}

The current research adopted Schiro's (2008) curriculum ideologies as a framework (Table 1). This is because Schiro (2008) provides a condensed summary of ideologies based on various curriculum ideologies documented in literature. He shows that there are at least four ideologies. These are defined here as discipline-centred ideology, service-centred ideology, student-centred ideology and citizenship-centred ideology. Each ideology is based on the view that there are six components of the curriculum through which a curriculum ideology could be understood. These are the purpose of the subject, the nature of knowledge, the instructional process (including teaching and learning), the role of the teachers, the role of the students and the assessment.

The primary objective of the discipline-centred ideology is transmitting discipline-specific knowledge, by teaching students epistemological and ontological principles of the discipline (Schiro, 2008). This is done to preserve the autonomy of academic disciplines and the associated knowledge (Cotti \& Schiro, 2004; Ravitch, 2000; Schiro, 2008). The curriculum in this ideology is regarded as unchallengeable high ground and impregnable fortresses that is immune to the effects of curriculum reform and socio-political dynamics (Goodson, 1992; Kliebard, 2004; Venville, Wallace, Rennie \& Malone, 2002).

The service-centred ideology shifts the focus from the discipline to the society, particularly the services that the graduate must offer (Schiro, 2008). In this ideology therefore, faculty is responsible for identifying societal problems and then develop learning programmes that will help students develop necessary skills required in providing services to the society. The learning programmes therefore are systematically derived from a particular role, or task, 
considered important to do a particular job (Abbatt \& McMahon, 1993). Curriculum designers in this regard identify and transform knowledge and skills into learning objectives, which in turn are arranged into learning experiences.

In the student-centred ideology, teaching and learning is focused on the student, his interests and abilities and students are allowed to construct their own knowledge and develop skills (Schiro, 2008). Teaching therefore is a nurturing process where teachers are facilitators and mentors. The student-centred ideology is founded on the idea that "artisans learn to forge by forging, to carve by carving, to paint by painting...let children learn to write by writing, to sing by singing, and to reason by reasoning" (Schiro, 2008, p. 112). It is based on the notion that students' natural abilities and interests should be central to teaching to facilitate the growth of students by helping them develop their skills and abilities further.

Citizenship-centred ideology is seen as the ideology that supports principles of citizenship education (Mnguni, 2017). In this ideology, students are viewed as members of the community in which they live; who have the ability to influence and be influenced by the norms, values and practices of their societies through intelligence and knowledge (Cotti \& Schiro, 2004). Central to a citizenship-centred ideology therefore is the view that students must acquire knowledge and skills that will enable them to identify social ills and be able to reconstruct these into social benefits. This however means teaching and learning must occur within community settings, rather than isolated school classrooms that are divorced from the community, so that everyday dynamics of the society are an integral part of the curriculum. It is this form of education that could foster citizenship (Mnguni, 2013).

Research has shown nonetheless that curriculum ideologies are only ideals (Mnguni, 2013). In reality, curricula tend to have a mélange of ideologies, slightly preferring one view over others in particular aspects (Mnguni, 2017; Kliebard, 2004). What is important however is that curriculum designers and teachers have an understanding of the founding curriculum theory of their respective curriculum and minimize confusion in terms of their curriculum and instructional design, confusion that may lead to teaching and learning difficulties.

\section{Aim of the Research}

Emanating from the above discourse, the aim of the current research was to investigate the curriculum ideology recommended by South African novice teachers in Life Sciences, in order to determine the extent to which they support citizenship education. The research question in this regard was:

\section{Which curriculum ideology do novice teachers recommend should inform Life Sciences?}

A response to this question would be significant to teacher-training institutions and curriculum designers, as it would demonstrate possible discrepancies between teachers' recommended ideology and the curriculum intentions, which may compromise the effective implementation of the curriculum thereby compromising the realization of its intentions.

\section{METHODOLOGY}

\section{Research Design}

In pursuing the current research, the researcher adopted a multiplistic realism research paradigm. This paradigm was selected because of its flexibility in accommodating mixed-methods and multiplistic epistemologies (Krauss, 2005). As a result, the researcher followed the explanatory concurrent mixed-method approach for data collection where the open-ended qualitative data were used to explain the closed-ended quantitative data.

\section{Sampling}

Concerning selecting participant, the researcher followed a non-probability convenience sampling approach to select forty-two novice Life Sciences teachers, who were part-time Bachelor of Education Honours students majoring in Science Education, with particular interest in Biology Education. Life Sciences is a school subject, previously known as biology, which is taught in Grades 10 to 12. The participants had completed a Bachelor's degree in Education in the previous two years. In the undergraduate programme all participants were exposed to the structure and contents of the CAPS Life Sciences (Department of Basic Education 2011). This included reading through the curriculum documents, preparing lesson plans guided by the CAPS Life Sciences as well as implementing aspects of the curriculum during teaching practice. They had all passed related examinations. Thirtysix percent $(36 \%)$ of the participants identified themselves as male, while $66 \%$ identified as female. Forty three percent $(43 \%)$ of the participants were working in well-resourced schools, while $57 \%$ were from under-resourced schools. All participants were either in their first or second year of work as Life Sciences teachers in government 
schools in Gauteng in which the CAPS Life Sciences curriculum was mandatory. These relatively novice teachers were selected in order to determine their recommendations based solely on theoretical knowledge rather than extensive experience. Further research is being carried out to determine experienced teachers recommendations. Participation in the research was voluntary and carried no incentives to the participants. The research was granted ethical clearance by the university in which it was carried out (Ethical Clearance Number: 2015-066).

\section{Data Collection}

During the research, participants were first given two one hour lectures on curriculum ideologies by the researcher who is a science education curriculum specialist, based on Schiro's (2008) and Mnguni's (2013) research on curriculum ideologies. This was to provide participants with an understanding of the concept of curriculum ideology as well as the different types of curriculum ideologies. No content knowledge assessment was conducted following these lectures. A week after the lectures, the participants were indirectly asked to recommend the curriculum ideology that should inform the purpose of the Life Sciences, the nature of knowledge in Life Sciences, the instructional process (including teaching and learning), the role of the teachers, the role of the students and the assessment in Life Sciences and ultimately the subject itself. To do this, participants were asked to respond to a semi-structured questionnaire, which was made up of six questions. Each question represented the six components of the curriculum (Schiro, 2008; Mnguni, 2013). Within each were four statements summarizing each curriculum ideology in no particular order. These statements were adapted from Schiro's (2008) standard inventory for curriculum analysis aimed at determining a curriculum ideology. Participants were therefore asked to rank these statements in the order of what they perceived, based on their training should be the primary focus in Life Sciences. Participants were not told that the statements were representing the ideologies. They were however asked to explain their ranking of the statements. A panel of three independent science education curriculum experts who confirmed content and face validity evaluated the questionnaires used in the research. The questionnaire was also piloted on a group of final year Bachelor of Education students where reliability was tested. The reliability coefficient in this regard was .78.

\section{Data Analysis}

For example, one question asked the participants to read statements a - $\mathrm{d}$ below carefully and then rank the statements from 1 to 4 , placing:

\section{1 - next to the statement that they recommend should be the first priority of Life Sciences \\ 2- next to the statement that they recommend should be the second priority of Life Sciences \\ 3- next to the statement that they recommend should be the third priority of Life Sciences \\ 4- next to the statement that they recommend should be the fourth priority of Life Sciences}

Participants were allowed to place the same priority on different statements where they thought it was necessary.

a) The purpose of Life Sciences should be to provide an enjoyable, stimulating, students-centred environment organized around the developmental needs and interests of students as those needs and interests present themselves from day to day.

b) The purpose of Life Sciences should be to provide students with the ability to perceive problems in society, envision a better society, and act to change society so that there is social justice and a better life for all people.

c) The purpose of Life Sciences should be to provide should be the creation of communities where the accumulated knowledge of the culture is transmitted to the students.

d) The purpose of Life Sciences should be to provide should be the fulfillment of the needs of society by efficiently training students to function as mature constructive members of society

While the above statements have overlaps between the different ideologies, each one of them predominantly reflects the principles of a specific curriculum ideology (see Table 1, Schiro, 2008). Statement a) to d) above reflected a predominantly student-centred ideology, citizenship-centred ideology, discipline centred ideology and servicecentred ideology respectively. The responses were then quantified descriptively to determine the ranking patters of the different ideologies amongst the participants. 


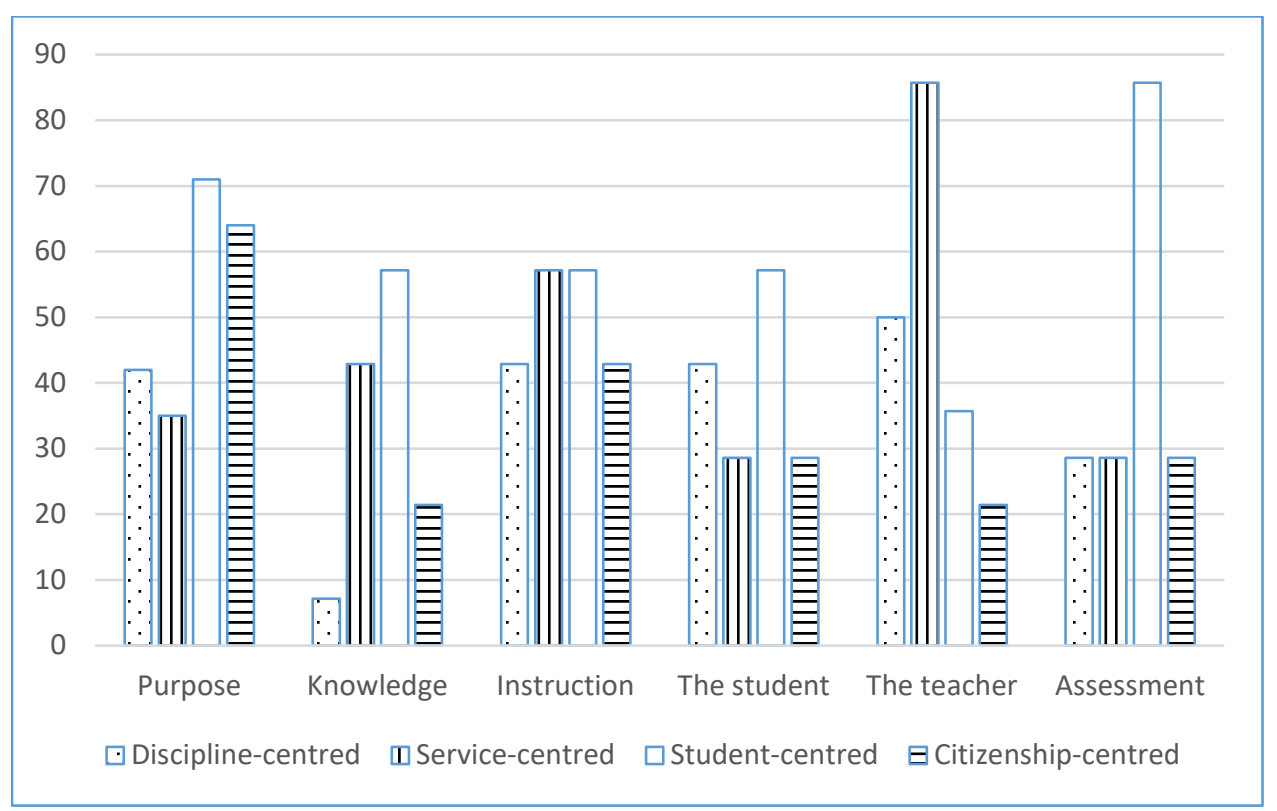

Figure 1. Participants' recommended ideology for Life Sciences

\section{RESULTS OF RESEARCH}

The percentage scores presented below are non-cumulative given the fact that respondents were asked to rank the statements in order of their recommendation, where some statements were ranked equally.

Results (Figure 1) show that the most recommended curriculum ideology amongst the participants was the student-centred ideology $(61 \%)$, followed by service-centred $(46 \%)$. The citizenship-centred ideology was least recommended with only $34 \%$ of the participants supporting it. The student-centred ideology was recommended by over $50 \%$ of the participants in five of the six components of the curriculum (see Figure 1). In fact, the studentcentred ideology received the lowest score only in the instructional process, where it was recommended third. The citizenship-centred ideology was the least recommended, by less than $30 \%$ of the participants in four of the six components of the curriculum. It however received the second highest recommendation in the purpose of the subject.

Statistical analysis of the data showed that gender does not correlate with the recommended curriculum ideology as well as between the type of school (well-resourced and under-resourced) and the recommended curriculum ideology $(\mathrm{p}>$.001).

\section{Purpose of Life Sciences}

Looking at the purpose of the subject, results show that the student-centred ideology was the most recommended amongst the participants (ranked first by $71 \%$ of the participants) while service-centred was least recommended. Most participants $(71 \%)$ indicated that "Life Sciences classrooms should be an enjoyable, stimulating, students-centred environment organized around the developmental needs and interests of students as those needs and interests present themselves from day to day". The citizenship-centred ideology received the second most recommendation with $64 \%$ of the participants suggesting that "Life Sciences should provide students with the ability to perceive problems in society, envision a better society, and act to change society so that there is social justice and a better life for all people."

\section{Nature of Knowledge}

Regarding the nature of knowledge, participants' recommendation was in line with the student-centred ideology. Here $57 \%$ of the participants indicated that "the knowledge of most worth is the personal meaning of oneself and of one's world that comes from one's direct experience in the world and one's personal response to such experience." The participants least recommended the discipline-centred ideology with only $7 \%$ indicating that "the knowledge of most worth is the structured knowledge and ways of thinking that have come to be valued by the culture over time". 


\section{Instructional Process}

There was no clear stand-out ideology recommended for the instructional process. For example, both the service-centred and student-centred ideologies were recommended by $57 \%$ of the participants, while both discipline-centred and citizenship-centred ideologies were recommended by $43 \%$ of the participants. Concerning service-centred, the participants indicated that "learning best proceeds when the student is presented with the appropriate stimulus materials and positive reinforcement." They also indicated that "learning best takes place when students are motivated to actively engage in experiences that allow them to create their own knowledge and understanding of the world in which they live" which is indicative of the student-centred ideology.

\section{Role of the Student}

Asked about the role of students during learning, most participants (57\%) indicated that "studentship is essentially a time when students unfold according to their own innate natures, felt needs, organic impulses, and internal timetables. The focus is on students as they are during childhood rather than as they might be as adults." This view was indicative of the student-centred ideology. Twenty nine percent $(29 \%)$ of the participants indicated that learning "is essentially a time for practice in and preparation for acting upon society to improve both oneself and the nature of society." This is indicative of the citizenship-centred ideology.

\section{Role of the Teacher}

With regard to the role of the teacher, the majority of participates recommended the service-centred ideology $(86 \%)$. Here the participants indicated that "teachers should be supervisors of learning, utilizing instructional strategies that will optimize student learning." Only a few participants $(21 \%)$ were recommended the citizenshipcentred ideology indicating that "teachers should be companions to students, using the environment within which the students lives to help the students learn." Similarly, the student-centred ideology was also recommended by few participants with only $36 \%$ saying, "Teachers should be aids to students, helping them learn by presenting them with experiences from which they can make meaning".

\section{Assessment}

Eighty six percent $(86 \%)$ of the participants supported the student-centred ideology in relation to assessment. Participants in this regard indicated that "assessment should continuously diagnose students' needs and growth so that further growth can be promoted by appropriate adjustment of their learning environment. It is primarily for the students' benefit, not for comparing students with each other or measuring them against predetermined standards." All the other ideologies received a similar score of $28 \%$.

\section{DISCUSSION OF THE RESULTS}

Researchers (e.g. Alsubaie, 2016; Lee, et al., 2011) have pointed out that teachers are significant agents of curriculum change and their preparedness to adopt curriculum reforms is crucial in shaping the success or failure of curriculum change. This preparedness is improved through teacher training as suggested by Lee and Yin (2005). In light of this, the major finding of the current research was that most participating teachers recommended the student-centred ideology and service-centred ideology for Life Sciences. The majority of the teachers did not recommend the discipline-centred and citizenship-centred ideologies. According to Mnguni (2013) and Mnguni (2017) the discipline-centred and student-centred ideologies are most reflected in the Life Sciences curriculum document. Apparently therefore, the student-centred ideology is the only ideology recommended by both teachers and the curriculum document. In the student-centred ideology, students are active participants during learning. This ideology supports the stimulation of growth and development of students (Posner, 1992; Schiro, 2008). In fact, knowledge itself is derived from students' personal and creative response to social and academic experiences. In the student-centred ideology, knowledge is viewed as students' personal meanings as constructed by students themselves (Schiro, 2008; Cotti \& Schiro, 2004). What is emerging from these findings therefore is that teachers may not always recommend the curriculum ideology reflected in the curriculum. The extent to which this may affect curriculum implementation needs exploration.

The researcher argues however that an "ideological conflict" may emerge because aspects of the student-centred ideology (supported by teachers and the curriculum document) are somewhat direct opposite those of the discipline-centred ideology, which is adopted by the Life Sciences curriculum but not recommended by teachers. The manifestation of this ideological conflict may be through a resistance in the implementation of the curriculum among teachers (Bantwini \& King-McKenzie, 2011) who may not support the discipline-centred ideology. This may be exacerbated by the fact that the curriculum reforms in South African were meant to promote citizenship 
education to ensure that students, and the society, become clear-thinking and enlightened citizens who participate in the reconstruction and empowerment of the society (Waghid, 2002). Yet as shown in the current and previous research (e.g. Mnguni, 2013), the Life Sciences curriculum and teachers do not recommend the citizenship-centred ideologies, which is fundamental to citizenship education. In the citizenship-centred ideology students are afforded an opportunity to interpret scientific knowledge within the context of their everyday life. By not recommending this ideology therefore, teachers may not integrate socio-scientific issues in their teaching, which are meant to bridge the gap between science and society. It is perhaps for this reason that Mnguni and Abrie (2012) as well as Mnguni, Abrie and Ebersöhn (2016) found that in Life Sciences students are taught HIV/AIDS knowledge as "academic knowledge" rather than "functional knowledge". As a result, students fail to apply this knowledge in their behavioural practices related to HIV/AIDS. The current researcher therefore posits that one of the reasons for this could be the apparent low support for the citizenship-centred ideology, which emphasizes the need to use lived experiences to teach scientific knowledge.

The current research also showed that the participating teachers recommended multiple ideologies. For example, teachers strongly support the service-centred ideology in the instruction process, but recommend the student-centred ideology for assessment. While it is probably impossible and not necessary for all teachers to adopt exclusively a single ideology (Mnguni, 2013), the researcher posits that the adoption of conflicting ideologies may be problematic. For example, interchanging ideologies in teaching and assessing may lead to learning difficulties for students, who are taught within one ideology and assessed in another.

\section{CONCLUSION}

The findings of the current research shed some light into the apparent resistance into the implementation of the curriculum in South Africa. The researcher suggests that this resistance could stem from ideological conflict between teachers and the curriculum on the purposes of education, the nature of the student, the way learning must take place, the role of the teacher during instruction, the nature of knowledge, and the nature of assessment. The researcher also argues that the lack of consistency in the recommended curriculum ideology among teachers may lead to added challenges regarding the implementation of new curricula. The researcher also concludes that the aspirations of the democratic South Africa to adopt citizenship education may not be realized due to minimal support for the citizenship-centred ideology.

While teacher-training programmes were not evaluated in the current research, the researcher believes that it is imperative that curriculum theory and curriculum design related to curriculum reforms must be addressed significantly. Further research is required however to determine possible links between conflicting ideologies and the implementation of the curriculum. Research is also required to determine the curriculum ideology of teachers, including experienced teacher, at a larger scale and across different school subjects.

\section{ACKNOWLEDGEMENTS}

The South African National Research Foundation (NRF) is appreciated for funding the research (GUN 99210).

\section{REFERENCES}

Abbat, F., \& McMahon, R. (1993). Teaching health-care workers: A practical guide. Houndmills: MacMillan Education Ltd.

Ajzen, I. (1991). The theory of planned behaviour. Organizational Behaviour and Human Decision Processes, 50, 179211. https:/ / doi.org/10.1016/0749-5978(91)90020-T

Alsubaie, M. A. (2016). Curriculum Development: Teacher Involvement in Curriculum Development. Journal of Education and Practice, 7(9), 106-107.

Bantwini, B. D. (2010). How teachers perceive the new curriculum reform: Lessons from a school district in the Eastern Cape Province, South Africa. International Journal of Educational Development, 30(1), 83-90. https:/ / doi.org/10.1016/j.ijedudev.2009.06.002

Bantwini, B. D., \& King-McKenzie, E. L. (2011). District officials' assumptions about teacher learning and change: Hindering factors to curriculum reform implementation in South Africa. International Journal of Education, 3(1), 1-25. https://doi.org/10.5296/ije.v3i1.655

Bulut, M. (2007). Curriculum Reform in Turkey: A Case of Primary School Mathematics Curriculum. Eurasia Journal of Mathematics, Science \& Technology Education, 3(3), 203-212. https:/ / doi.org/10.12973/ ejmste/75399

Chisholm, L. (2003). The state of curriculum reform in South Africa: The issue of Curriculum 2005. State of the Nation South Africa, 2004, 268-289. 
Cotti, R., \& Schiro, M. (2004). Connecting teacher beliefs to the use of children's literature in the teaching of mathematics. Journal of Mathematics Teacher Education, 7(4), 329-356. https://doi.org/10.1007/s10857-004$1787-\mathrm{z}$

Department of Basic Education. (2011). Life Sciences. Curriculum and Assessment Policy Statement Grade 10-12. ISBN: 978-1-4315-0578-4. Retrieved from www.thutong.doe.gov.za

Du Plessis, E. (2013). Introduction to CAPS. Curriculum \& Instructional Studies, Unisa.

Eacute, J., \& Esteve, M. (2000). The transformation of the teachers' role at the end of the twentieth century: New challenges for the future. Educational Review, 52(2), 197-207. https:/ / doi.org/10.1080/713664040

Gagne, R. M. (1967). Curriculum research and the promotion of learning. Perspectives of curriculum evaluation, $19-38$.

Goodlad, J. I., \& Associates. (1979). Curriculum inquiry: the study of curriculum practice. New York: McGraw-Hill.

Goodson, I. F. (1992). On curriculum form: Notes toward a theory of curriculum. Sociology of education, 66-75. https:/ / doi.org/10.2307/2112693

Huang, F. (2004). Curriculum reform in contemporary China: Seven goals and six strategies. Journal of Curriculum Studies, 36(1), 101-115. https:/ / doi.org/10.1080/002202703200004742000174126

Jansen, J. D. (1998). Curriculum reform in South Africa: A critical analysis of outcomes-based education. Cambridge journal of education, 28(3), 321-331. https:/ / doi.org/10.1080/0305764980280305

Kelchtermans, G. (2005). Teachers' emotions in educational reforms: Self-understanding, vulnerable commitment and micropolitical literacy. Teaching and Teacher Education, 21(8), 995-1006. https:/ / doi.org/10.1016/j.tate.2005.06.009

Kliebard, H. M. (2004). The struggle for the American curriculum 1893-1958 (3rd ed). New York: Routledge Falmer.

Krauss, S. E. (2005). Research paradigms and meaning making: A primer. The qualitative report, 10(4), 758-770.

Kurz, A., Elliott, S.N., Wehby, J. H., \& Smithson, J. L. (2010). Alignment of the intended, planned and enacted curriculum in general and special education and its relation to student achievement. The Journal of Special Education, 44(3), 131-145. https:/ / doi.org/10.1177/0022466909341196

Le Grange, L. (2016). Decolonising the university curriculum: leading article. South African Journal of Higher Education, 30(2), 1-12.

Lee, J. C. K., \& Yin, H. B. (2005). Teacher receptivity to and concerns about curriculum change: An exploration of research on curriculum implementation. Journal of Educational Research and Development, 1(1), 107-128.

Lee, J. C. K., Yin, H. B., Zhang, Z. H., \& Jin, Y. L. (2011). Teacher empowerment and receptivity in curriculum reform in China. Chinese Education E Society, 44(4), 64-81. https:/ / doi.org/10.2753/CED1061-1932440404

Luescher, T., Loader, L., \& Mugume, T. (2017). \#FeesMustFall: An Internet-age student movement in South Africa and the case of the University of the Free State. Politikon, 44(2), 231-245. https:/ / doi.org/10.1080/02589346.2016.1238644

Mandela, N. (2003). Lighting your way to a better future. Speech delivered at the launch of Mindset Network. Planetarium, University of Witwatersrand, Johannesburg, South Africa, 16.

Mnguni, L. (2013). The curriculum ideology of the South African secondary school Biology. South African Journal of Education, 33(2), 1-11. https:/ / doi.org/10.15700/saje.v33n2a700

Mnguni, L. (2017). "Ideological wars" in the South African Natural Sciences \& Technology and Life Sciences curricula. 12 $2^{\text {th }}$ Conference of the European Science Education Research Association (ESERA). 21-25 August 2017, Dublin City University, Ireland.

Mnguni, L. E., \& Abrie, A. L. (2012). HIV/AIDS content knowledge and modes of presentation in Biology for effective use in everyday life. Journal of Biological Education, 46(4), 226-233. https:/ / doi.org/10.1080/00219266.2012.716778

Mnguni, L. E., Abrie, A. L., \& Ebersöhn, L. (2016). The Relationship between Scientific Knowledge and Behaviour: An HIV/AIDS Case. Journal of Biological Education, 50(2), 147-159. https:/ / doi.org/10.1080/00219266.2015.1007888

Msila, V. (2007). From apartheid education to the Revised National Curriculum Statement: Pedagogy for identity formation and nation building in South Africa. Nordic Journal of African Studies, 16(2), 146-160.

Pietarinen, J., Pyhältö, K., \& Soini, T. (2017). Large-scale curriculum reform in Finland-exploring the interrelation between implementation strategy, the function of the reform, and curriculum coherence. The Curriculum Journal, 28(1), 22-40. https:/ / doi.org/10.1080/09585176.2016.1179205

Popham, W. J., \& Baker, E. I. (1970). Systematic instruction. Englewood Cliffs, NJ: Prentice Hall. 
Porter, R. E., Fusarelli, L. D., \& Fusarelli, B. C. (2015). Implementing the Common Core: How educators interpret curriculum reform. Educational Policy, 29(1), 111-139. https:/ / doi.org/10.1177/0895904814559248

Posner, G. J. (1992). Analyzing the Curriculum. New York: McGraw-Hill.

Ramatlapana, K., \& Makonye, J. P. (2012). From too much freedom to too much restriction: The case of teacher autonomy from National Curriculum Statement (NCS) to Curriculum and Assessment Statement (CAPS). Africa Education Review, 9(sup1), S7-S25. https:/ / doi.org/10.1080/18146627.2012.753185

Ravitch, D. (2000). The great school wars: A history of the New York City public schools. Baltimore: JHU Press.

Schiro, M. S. (2008). Curriculum theory: Conflicting visions and enduring concerns. California: Sage Publications.

Spaull, N. (2013). South Africa's education crisis: The quality of education in South Africa 1994-2011. Johannesburg: Centre for Development and Enterprise, 1-65.

Stuckey, M., Hofstein, A., Mamlok-Naaman, R., \& Eilks, I. (2013). The meaning of 'relevance' in science education and its implications for the science curriculum. Studies in Science Education, 49(1), 1-34. https:// doi.org/10.1080/03057267.2013.802463

Sweetland, S. R., \& Hoy, W. K. (2000). School characteristics and educational outcomes: Toward an organizational model of student achievement in middle schools. Educational Administration Quarterly, 36(5), 703-729. https:// doi.org/10.1177/00131610021969173

Van Deventer, K. (2009). Perspectives of teachers on the implementation of Life Orientation in Grades R-11 from selected Western Cape schools. South African Journal of Education, 29(1), 127-145. https:/ / doi.org/10.1590/S0256-01002009000100008

Venville, G. J., Wallace, J., Rennie, L. J., \& Malone, J. A. (2002). Curriculum integration: Eroding the high ground of science as a school subject? Studies in Science Education, 37(1), 43-83. https://doi.org/10.1080/03057260208560177

Waghid, Y. (2002). Knowledge production and higher education transformation in South Africa: Towards reflexivity in university teaching, research and community service. Higher Education, 43, 457-488. https://doi.org/10.1023/A:1015211718131

\section{http://www.ejmste.com}

